\title{
ANALISIS FAKTOR-FAKTOR YANG MEMPENGARUHI PENDAPATAN PEDAGANG KAKI LIMA KOTA TARAKAN
}

\author{
THE ANALYSIS INFLUENCE OF MERCHANT STREET \\ VENDOR INCOME OF TARAKAN CITY
}

\author{
Syaiful Anwar ${ }^{1)}$, Rahayu Ambarsari ${ }^{2)}$ \\ (Universitas Bornepo Tarakan)
}

\begin{abstract}
Abstrak: Tujuan dari penelitian ini yaitu untuk memberikan informasi tentang faktorfaktor yang mempengaruhi tingkat pendapatan pedagang kaki lima Kota Tarakan (Study kasus di THM Plaza). Jumlah sampel dalam penelitian ini adalah 97 responden. Variabel dalam penelitian ini adalah Modal (X1), Jam Kerja (X2), dan Lama Usaha (X3). Metode yang digunakan dalam penelitian ini adalah kuesioner dengan wawancara. Data yang diolah menggunakan analisis regresi linier berganda dengan menggunakan Uji $t$, Uji F, serta Uji asumsi klasik.

Hasil penelitian ini menunjukkan bahwa secara simultan modal, jam kerja, dan lama usaha berpengaruh signifikan terhadap pendapatan pedagang kaki lima Kota Tarakan. Hal ini dibuktikan dari nilai $F$ statistik sebesar 3,676 > F tabel 2,70 dan nilai signifikan sebesar 0,014. Nilai $R_{2}$ sebesar 0,106 berarti bahwa 10,6\% variabel ini menjelaskan variasi pendapatan pedagang kaki lima di THM Plaza.Sedangkan sisanya sebesar 89,4\% diterangkan oleh variabel lain yang tidak terdapat dalam model. Selain itu, secara parsial jam kerja berpengaruh terhadap pendapatan pedagang kaki lima di THM Plaza. Karena $t$ statistik dari variabel jam kerja sebesar 3,214 lebih besar daripada t tabel sebesar 1,985 sedangkan modal dan lama usaha secara parsial tidak berpengaruh terhadap pendapatan pedagang kaki lima di THM Plaza. Karena t hitung dari variabel modal dan lama usaha masingmasing sebesar 0,869 dan (-0,395) lebih kecil daripada t tabel sebesar 1,985.
\end{abstract}

\section{Kata Kunci : Modal, Jam Kerja, Lama Usaha dan Pendapatan Pedagang Kaki Lima}

Abstract: The purpose of this research to give the information about the influence of factors merchant street vendor income level of Tarakan city (case of study at THM Plaza). The total of sample of this research is 97 Respondents. The variable in this research is capital $\left(X_{1}\right)$, Working Hours ( $\left.X_{2}\right)$, Long Business (X3). This research used method are questionnaire by interviewed. The analysis data used multiple linier regression analysis by using t-test, F-test and classic assumption test.

The result of this research showed the capital, working hours, and long business give the significant influence of merchant street vendor income of Tarakan City. It is proven by $F$ statistic 3,676 > F table 2,70 and significant score is 0,014. $R_{2}$ value is 0,106 so the variable is 10,6\% this variable explained the variation merchant street vendor income at THM Plaza.

While the rest is $89,4 \%$ result the another variable was not in capital. Other than partially, working hours give the influence to merchant street vendor income at THM Plaza. $t$ statistic of the working hours variable is 3,214 larger on t table is 1,985 and then the capital and long business partially didn't have influence to merchant street vendor income at THM Plaza. $t$ value of capital variable and long business are 0,869 and (-0,395) smaller than $t$ table is 1,985. Keyword: Capital, Working Hours, Long Business and Merchant Street Vendor Income.

Keyword: Capital, Working Hours, Long Business and Merchant Street Vendor Income 


\section{LATAR BELAKANG}

Sektor informal memiliki karakteristik seperti jumlah unit usaha yang banyak dalam skala kecil, kepemilikan oleh individu atau keluarga, teknologi yang sederhana dan padat tenaga kerja, tingkat pendidikan dan keterampilan yang rendah, akses ke lembaga keuangan daerah, produktivitas tenaga kerja yang rendah dan tingkat upah yang juga relatif lebih rendah dibandingkan sektor formal (Wibowo, 2005). Terbukti sulitnya lapangan pekerjaan yang tersedia bagi anggota masyarakat yang berpendidikan rendah dengan pengalaman serta keterampilan yang sangat terbatas, sektor informal mampu memegang peranan penting menampung angkatan kerja, terutama angkatan kerja muda yang masih belum berpengalaman atau angkatan kerja yang pertama kali masuk pasar kerja (Fatmawati, 2014). Salah satu contoh sektor informal adalah pedagang kaki lima (PKL).

Tarakan Harus Membangun atau yang lebih dikenal dengan sebutan THM Plaza merupakan salah satu obyek wisata belanja yang terdapat di Kota Tarakan. Lokasinya berada dijalan Yos Sudarso, kecamatan Karang Balik yang beroperasi setiap hari antara pukul 03.00 sore sampai pukul 23.00 malam. Pedagang kaki lima di THM Plaza menjual berbagai macam jenis barang dagangan seperti makanan, minuman, pakaian, aksesoris, perlengkapan sekolah, peralatan dapur, dan lain-lain. Namun, meskipun jenis barang dagangan yang dijual berbeda, tujuan mereka tetap sama yaitu untuk memperoleh keuntungan maksimal.

\section{RUMUSAN MASALAH}

Berdasarkan latar belakang yang telah disampaikan maka terdapat beberapa rumusan masalah yang dapat diajukan sebagai berikut :

1. Apakah faktor modal, jam kerja, dan lama usaha berpengaruh secara simultan terhadap pendapatan Pedagang Kaki Lima di THM Plaza?
2. Apakah faktor modal, jam kerja, dan lama usaha berpengaruh secara parsial terhadap pendapatan Pedagang Kaki Lima di THM Plaza?

\section{TUJUAN PENELITIAN}

1. Untuk menganalisis pengaruh modal, jam kerja, dan lama usaha secara simultan terhadap pendapatan Pedagang Kaki Lima di THM Plaza.

2. Untuk menganalisis pengaruh modal, jam kerja, dan lama usaha secara parsial terhadap pendapatan Pedagang Kaki Lima di THM Plaza.

\section{TINJAUAN PUSTAKA}

\section{$\underline{\text { Sektor Informal }}$}

Sektor informal ialah suatu usaha yang dimiliki dan dikelola secara bebas dan yang menjalankan bisnis adalah pemilik sendiri, bekerja bebas sesuai kesanggupannya (Alma Buchari, 2006).

Para pekerja yang menciptakan sendiri lapangan kerjanya disektor informal biasanya tidak memiliki pendidikan formal. Pada umumnya mereka tidak mempunyai keterampilan khusus dan sangat kekurangan dalam hal modal kerja. Oleh sebab itu, produktivitas dan pendapatan mereka cenderung lebih rendah daripada kegiatan kegiatan bisnis yang ada disektor formal. Selain itu, mereka yang berada disektor informal juga tidak memiliki jaminan keselamatan kerja dan fasilitas-fasilitas kesejahteraan seperti yang dinikmati rekan rekan yang berada disektor formal, misalnya tunjangan keselamatan kerja dan dana pensiun (Todaro, 2000).

Ciri-Ciri sektor informal di antaranya (Alma Buchari, 2006)

1. Kegiatan usaha tidak terorganisasi secara baik.

2. Belum mempunyai izin usaha yang resmi.

3. Teknologi yang digunakan sangat sederhana.

4. Modal dan perputaran usaha sangat kecil.

5. Pendidikan formal dari para pengelolanya tidak menjadi pertimbangan dalam membuka usaha. 
6. Usahanya bersifat mandiri, jika ada

karyawan biasanya dari keluarga sendiri.

Wirosardjono dalam Budi (2006)

mendefinisikan sektor informal sebagai sektor

kegiatan kecil yang mempunyai ciri-ciri sebagai berikut :

1. Pola kegiatan tidak teratur baik dalam arti waktu, permodalan, maupun penerimaannya.

2. Tidak tersentuh oleh ketentuan atau peraturan yang ditetapkan oleh pemerintah.

3. Modal, peralatan, dan perlengkapan maupun omset-omsetnya biasanya kecil dan atas dasar hitungan harian.

4. Umumnya tidak mempunyai tempat usaha yang permanen.

5. Tidak mempunyai keterikatan dengan usaha lain yang besar.

6. Umumnya dilakukan oleh dan melayani golongan masyarakat yang berpendapatan rendah.

7. Tidak membutuhkan keahlian dan keterampilan khusus sehingga dapat menyerap bermacam-macam tingkat tenaga.

8. Tidak mengenal sistem perbankan, pembukuan, dan lain sebagainya.

9. Umumnya tiap satuan usaha memperkerjakan tenaga kerja yang sedikit dan berasal dari lingkungan keluarga, kenalan, atau dari daerah yang sama.

Clifford M.Baumback Ph.D

menyatakan ciri sektor informal (Alma

Buchari, 2006) :

1. Manejemen oleh pemilik.

2. Sangat tergantung pada pribadi seseorang

3. Daerah operasional bersifat lokal

4. Permodalan sangat bergantung pada sumber dari dalam bisnis

\section{Bisnis Kecil}

Kegiatan bisnis kecil yang bergerak dalam bidang perdagangan dapat diklasifikasikan secara garis besar yaitu (Alma Buchari, 2006) :

1. Skala besar dengan modal lebih dari Rp.100 juta.

2. Skala menengah dengan modal Rp.25 juta - Rp.100 juta.
3. Skala kecil dengan modal dibawah Rp.25 juta.

Kelemahan bisnis kecil yaitu (Alma Buchari, 2006) :

1. Pendapatan pengusaha bisnis kecil tidak menentu, tidak tetap dibandingkan dengan menerima gaji tetap dari perusahaan.

2. Resiko pengusaha lebih besar dibandingkan dengan seseorang yang bekerja di perusahaan.

3. Dalam keadaan sulit maka saat-saat membayar gaji pegawai dirasakan merupakan beban berat. Tetapi keadaan ini tidak akan terasa bila keadaan telah lancar kembali.

4. Pengusaha dibatasi geraknya oleh berbagai peraturan yang dikeluarkan oleh pemerintah pusat, kotamadya, kecamatan, RT, RW, dan sebagainya.

Kelebihan bisnis kecil antara lain :

1. Pengusaha memiliki kebebasan yang luas dalam menjalankan usahanya sendiri. Ini merupakan satu keuntungan bagi pengusaha karena hidup aman dan tidak ada tekanan.

2. Pengusaha mampu mengekspresikan ide ide yang dimiliki dengan mudah. Tidak seperti bisnis besar yang banyak melalui birokrasi sehingga untuk mengekspresikan ide cenderung sulit.

3. Pemilik usaha bisnis kecil menikmati keuntungan sendiri.

4. Pengusaha bisnis kecil lebih cenderung mudah mendapatkan penghargaan masyarakat, dibandingkan seseorang yang bekerja di perusahaan.

\section{Usaha Mikro, Kecil, dan Menengah}

Pada saat terjadi krisis ekonomi pada tahun 1998, hanya sektor UMKM yang bertahan dari kolapsnya ekonomi, sementara sektor yang lebih besar justru tumbang oleh krisis (Berry dkk, 2006). Usaha Mikro Kecil dan Menengah (UMKM) hadir sebagai solusi dari sistem perekonomian yang sehat. Sektor Usaha Mikro Kecil dan Menengah (UMKM) merupakan salah satu faktor industri yang sedikit bahkan tidak sama sekali terkena dampak krisis global yang mendunia (Venkatesh, 2006). Dengan bukti ini, jelas bahwa UMKM dapat diperhitungkan dalam 
meningkatkan persaingan pasar dan stabilisasi sistem perekonomian yang ada saat ini (Kementrian Koperasi dan Usaha Kecil Menengah, 2012).

Berdasarkan Undang-Undang Nomor 20 Tahun 2008 tentang Usaha Mikro, Kecil, dan Menengah (UU UMKM) Pasal 1 angka

(1), (2), dan (3) :

1. Usaha Mikro adalah usaha produktif milik orang perorangan dan/atau badan usaha perorangan yang memenuhi kriteria Usaha Mikro sebagaimana diatur dalam UU UMKM.

2. Usaha Kecil adalah usaha ekonomi produktif yang berdiri sendiri, yang dilakukan oleh orang perorangan atau badan usaha yang bukan merupakan anak perusahaan atau bukan cabang perusahaan yang dimiliki, dikuasai, atau menjadi bagian baik langsung maupun tidak langsung dari usaha menengah atau usaha besar yang memenuhi kriteria Usaha Kecil sebagaimana dimaksud dalam UU UMKM.

3. Usaha Menengah adalah usaha ekonomi produktif yang berdiri sendiri, yang dilakukan oleh orang perseorangan atau badan usaha yang bukan merupakan anak perusahaan atau cabang perusahaan yang dimiliki, dikuasai, atau menjadi bagian baik langsung maupun tidak langsung dengan usaha kecil atau usaha besar dengan jumlah kekayaan bersih atau hasil penjualan tahunan sebagaimana diatur dalam Undang-Undang UMKM.

Berdasarkan beberapa definisi UMKM diatas, maka dapat disimpulkan bahwa Usaha Mikro Kecil Menengah (UMKM) merupakan usaha kecil yang dapat menghasilkan omzet pertahunnya setinggitingginya Rp.200.000.000-Rp.600.000.000 tanpa termasuk tanah dan bangunan serta memiliki pekerja 5 sampai dengan 19 orang. Sedangkan usaha menengah merupakan entisitas usaha yang omzet pertahun paling banyak Rp.200.000.000 sampai dengan Rp. 10.000.000.000 diluar tanah dan bangunan dengan jumlah tenaga kerja 20-99 orang yang dilakukan oleh orang perorangan atau badan usaha.

Jenis usaha UMKM di Indonesia terdiri dari: 1) pertanian dan yang terkait dengan pertanian (agribisnis), 2) pertambangan rakyat dan penggalian, 3) industri kecil dan kerajinan rumah tangga, 4) listrik non-PLN, 5) konstruksi, 6) perdagangan besar, eceran kecil, rumah makan, 7) angkutan dan komunikasi, 8) lembaga keuangan, dan 9) real estate dan persewaan. Dengan pertumbuhan terbesar pada sektor industri kecil dan kerajinan rumah tangga; perdagangan besar, eceran, RM dan jasa akomodasi; angkutan dan komunikasi; dan real estate dan persewaan (Kementrian Koperasi dan UKM, 2012).

Secara umum, karakteristik UMKM di Indonesia kebanyakan berbentuk industri mikro yang beroperasi pada level rumahan dengan teknologi rendah dan tenaga kerja yang berpendapatan dan berkemampuan rendah (Tambunan, 2009). Selain itu, industri UMKM dengan produk yang sama cenderung berkumpul di satu daerah (clustering) karena banyak kemudahan, seperti kemudahan distribusi barang dan pemasaran yang didapat (Hill, 2001). Sumber modal dari UMKM berasal dari kredit dari bank, pribadi, campuran antara keduanya, atau sumber kredit informal lain (Struyk, 2011).

Dalam perspektif perkembangannya, sektor UMKM dewasa ini dapat diklasifikasikan menjadi empat kelompok yaitu (Sofia Hanni, 2009) :

1. Livelihood Activities, merupakan UMKM yang digunakan sebagai kesempatan kerja untuk mencari nafkah, yang lebih umum dikenal sebagai sektor informal. Contoh adalah pedagang kaki lima, pedagang di pasar dll.

2. Micro Enterprise, merupakan UMKM yang memiliki sifat pengrajin tetapi belum memiliki sifat kewirausahaan.

3. Small Dinamic Enterprise, merupakan UMKM yang telah memiliki jiwa kewirausahaan dan mampu menerima pekerjaan subkontrak dan ekspor.

4. Fast Moving Enterprise, merupkan UMKM yang telah memiliki jiwa kewirausahaan dan akan melakukan transformasi menjadi usaha besar.

Secara umum UMKM dalam perekonomian nasional memiliki peran :

1. Sebagai pemeran utama dalam kegiatan ekonomi. 
2. Penyedia lapangan kerja terbesar.

3. Pemain penting dalam pengembangan perekonomian lokal dan pemberdayaan masyarakat.

4. Pencipta pasar baru dan inovasi, serta ;

5. Kontribusinya terhadap neraca pembayaran (Departemen Koperasi dan UKM, 2012).

Oleh karena itu pemberdayaannya harus dilakukan secara terstruktur dan berkelanjutan, dengan arah peningkatan produktivitas dan daya saing serta menumbuhkan wirausahawan baru yang tangguh (Radam dkk, 2013). Salah satu keunggulan UMKM adalah sangat lincah mencari peluang untuk berinovasi untuk menerapkan teknologi baru dibandingkan dengan perusahaan-perusahaan yang sudah mapan (Struyk, 2011). Tidak mengherankan jika banyak perusahaan besar bergantung kepada pemasok-pemasok kecil dan menengah (Asghar, 2012). Sesungguhnya ini merupakan peluang untuk turut berkecimpung di era globalisasi sekaligus menggerakan sektor ekonomi riil bangsa (Sofia Hanni, 2009).

\section{Teori Pendapatan}

Pendapatan merupakan unsur yang
sangat penting dalam sebuah usaha
perdagangan, karena dalam melakukan suatu
usaha tentu ingin mengetahui nilai atau jumlah
pendapatan yang diperoleh selama melakukan
usaha tersebut (Paula, 2005). Dalam arti
ekonomi, pendapatan merupakan balas jasa
atas penggunaan faktor-faktor produksi yang
dimiliki oleh sektor rumah tangga dan sektor
perusahaan yang dapat berupa gaji/upah, sewa,
bunga serta keuntungan/profit (Sukirno,2000).
Pendapatan adalah suatu pertambahan asset
yang mengakibatkan bertambahnya owners
equity, tetapi bukan karena pertambahan
modal baru dari pemiliknya dan bukan pula
merupakan pertambahan asset yang
disebabkan karena bertambahnya liabilities.
Pendapatan sangat berpengaruh bagi
kelangsungan hidup perusahaan, semakin
besar pendapatan yang diperoleh maka
semakin besar kemapuan perusahaan untuk
membiayai segala pengeluaran dan kegiatan-
kegiatan yang akan dilakukan oleh perusahaan
(Munandar, 2006). Kondisi seseorang dapat

diukur dengan menggunakan konsep pendapatan yang menunjukkan jumlah seluruh uang yang diterima oleh seseorang atau rumah tangga selama jangka waktu tertentu (Samuelson dan Nordhaus, 2002).

Definisi lain dari pendapatan adalah jumlah penghasilan yang diperoleh dari hasil pekerjaan dan biasanya pendapatan seseorang dihitung setiap tahun atau setiap bulan. Dengan demikian pendapatan merupakan gambaran terhadap posisi ekonomi keluarga dalam masyarakat. Pendapatan keluarga berupa jumlah keseluruhan pendapatan dan kekayaan keluarga, dipakai untuk membagi keluarga dalam tiga kelompok pendapatan, yaitu: pendapatan rendah, pendapatan menengah dan pendapatan tinggi. Pembagian di atas berkaitan dengan status, pendidikan dan keterampilan serta jenis pekerja seseorang namun sifatnya sangat relatif. Sebagaimana pendapat di atas, bahwa pendapatan merupakan gambaran terhadap posisi ekonomi keluarga dalam masyarakat, oleh karenanya setiap orang yang bergelut dalam suatu jenis pekerjaan tertentu termasuk pekerjaan di sektor informal atau perdagangan, berupaya untuk selalu meningkatkan pendapatan dari hasil usahanya yang digunakan untuk memenuhi kebutuhan hidup keluarganya dan sedapat mungkin pendapatan yang diperoleh dapat meningkatkan taraf hidup keluarganya. Pendapatan dapat dihitung melalui tiga cara yaitu (Sukirno, 2000) :

1. Cara Pengeluaran. Cara ini pendapatan dihitung dengan menjumlahkan nilai pengeluaran/perbelanjaan ke atas barang barang dan jasa.

2. Cara Produksi. Cara ini pendapatan dihitung dengan menjumlahkan nilai barang dan jasa yang dihasilkan.

3. Cara Pendapatan. Dalam penghitungan ini pendapatan diperoleh dengan cara menjumlahkan seluruh pendapatan yang diterima.

Pendapatan adalah penerimaan bersih seseorang, baik berupa uang kontan maupun natura. Pendapatan atau disebut juga income dari seorang warga masyarakat adalah hasil penjualannya dari faktor-faktor produksi yang dimilikinya pada sektor produksi. Sektor produksi ini membeli faktor-faktor produksi tersebut untuk digunakan sebagai input proses 
produksi dengan harga yang berlaku di pasar faktor produksi. Harga faktor produksi di pasar (seperti halnya juga untuk barang-barang di pasar barang) ditentukan oleh tarik menarik, antara penawaran dan permintaan. Secara garis besar pendapatan digolongkan menjadi tiga golongan yaitu (Suparmoko, 2000) :

1. Gaji dan Upah. Imbalan yang diperoleh setelah orang tersebut melakukan pekerjaan untuk orang lain yang diberikan dalam waktu satu hari, satu minggu, maupun satu bulan.

2. Pendapatan dari Usaha Sendiri. Merupakan nilai total dari hasil produksi yang dikurangi dengan biaya-biaya yang dibayar dan usaha ini merupakan usaha milik sendiri atau keluarga dan tenaga kerja berasal dari anggota keluarga sendiri, nilai sewa milik sendiri dan semua biaya ini biasanya tidak diperhitungkan.

3. Pendapatan dari Usaha Lain. Pendapatan yang diperoleh tanpa mencurahkan tenaga kerja, dan ini biasanya merupakan pendapatan sampingan antara lain :

a. Pendapatan dari hasil menyewakan aset yang dimiliki seperti rumah.

b. Ternak dan barang lain.

c. Bunga dari uang.

d. Sumbangan dari pihak lain.

e. Pendapatan dari pensiun.

f. Dan lain-lain.

Pendapatan perseorangan adalah jumlah pendapatan yang diterima setiap orang dalam masyarakat yang sebelum dikurangi transfer payment. Transfer Payment yaitu pendapatan yang tidak berdasarkan balas jasa sedangkan pendapatan menurut bentuknya dibedakan menjadi (Todaro, 2000) :

1. Pendapatan berupa uang adalah segala penghasilan yang sifatnya reguler dan yang diterima biasanya sebagai balas jasa, sumber utamanya berupa gaji, upah, bangunan, pendapatan bersih dari usaha sendiri dan pendapatan dari penjualan seperti : hasil sewa, jaminan sosial, premi asuransi.

2. Pendapatan berupa barang adalah segala penghasilan yang sifatnya reguler dan biasanya tidak berbentuk balas jasa dan diterima dalam bentuk barang.
Menurut Yudhohusodo dalam Ariyani (2006), tingkat pendapatan seseorang dapat digolongkan dalam 4 golongan yaitu :

a. Golongan yang berpenghasilan rendah (low income group) yaitu pendapatan ratarata dari Rp. 150.000 perbulan.

b. Golongan berpenghasilan sedang (Moderate income group) yaitu pendapatan rata-rata Rp.150.000 Rp.450.000 perbulan.

c. Golongan berpenghasilan menengah (midle income group) yaitu pendapatan rata-rata yang diterima Rp.450.000 Rp.900.000 perbulan.

d. Golongan yang berpenghasilan tinggi (high income group) yaitu rata-rata pendapatan lebih dari Rp.900.000.

\section{$\underline{\text { Teori Biaya Produksi }}$}

Biaya produksi dapat didefinisikan sebagai semua pengeluaran yang dilakukan oleh perusahaan untuk memperoleh faktorfaktor produksi dan bahan-bahan mentah yang akan digunakan untuk menciptakan barangbarang yang diproduksi perusahaan tersebut. Biaya produksi sendiri dibedakan kepada dua jenis, yaitu (Sukirno, 2005) :

1. Biaya eksplisit, biaya eksplisit adalah pengeluaran-pengeluaran perusahaan yang berupa pembayaran dengan uang untuk mendapatkan faktor-faktor produksi dan bahan mentah yang dibutuhkan.

2. Biaya tersembunyi, biaya tersembunyi adalah taksiran pengeluaran terhadap faktor-faktor produksi yang dimiliki oleh perusahaan itu sendiri. Pengeluaran yang tergolong sebagai biaya tersembunyi adalah pembayaran untuk keahlian keusahawanan produsen tersebut, modalnya sendiri digunakan dalam perusahaan dan bangunan perusahaan yang dimilikinya (Sukirno, 1994).

Dalam suatu usaha berdagang jenis PKL ini, biasanya masyarakat dan pedagang sendiri menyebut biaya produksi dengan sebutan modal dalam kegiatan usaha mereka sehari hari. Modal atau biaya adalah salah satu faktor produksi yang sangat penting bagi setiap usaha, baik skala kecil, menengah maupun besar (Tambunan, 2002). Modal memiliki hubungan positif bagi bertambahnya 
pendapatan pedagang, dimana modal yang besar akan berpengaruh terhadap meningkatnya kapasitas produksi dan besarnya skala usaha. Tersedianya bahan baku dalam jumlah yang cukup dan berkesinambungan akan memperlancar produksi yang pada akhirnya akan meningkatkan jumlah produksi serta dapat berpengaruh pada jumlah pendapatan usaha yang diperoleh.

\section{$\underline{\text { Teori - Teori Yang Relevan }}$}

Menurut Sugiyono (2013), teori relevansi dalah serangkaian bagian atau variabel, definisi, dan dalil yang saling berhubungan dan cocok yang menghadirkan sebuah pandangan sistematis mengenai fenomena dengan menentukan hubungan antar variabel, dengan maksud menjelaskan fenomena alamiah yang terjadi dalam suatu penelitian. Relevansi merupakan informasi terpanggil dalam suatu pencarian sumber atau koleksi pustaka lainnya, dimana informasi yang diberikan sesuai dengan subyek pada penelitian dan berhubungan dengan kebutuhan penelitian (Kamus besar bahasa Indonesia). Dalam penelitian ini akan dikemukakan teori teori yang relevan dengan pendapatan pedagang atau pengusaha di sektor Usaha Mikro Kecil dan Menengah (UMKM). Dimana dalam suatu perekonomian, pendapatan merupakan faktor yang terpenting karena dengan adanya pendapatan maka kegiatan perekonomian dapat berjalan dengan baik (Yusbar Yusuf dkk., 2010). Pendapatan adalah proses kenaikan laba melalui proses arus penciptaan barang atau jasa oleh suatu perusahaan selama kurun waktu tertentu. Umumnya pendapatan dinyatakan dalam satuan moneter/uang (Tuanakota, 2000).

Faktor - faktor yang mempengaruhi pendapatan pedagang kaki lima :

Pada usaha perdagangan ada beberapa faktor yang mempengaruhi peningkatan produksi yang pada akhirnya akan mempengaruhi tingkat pendapatan yang akan diterima oleh pedagang. Adapun variabelvariabel yang mempengaruhi tingkat pendapatan adalah : Modal usaha, Lama usaha, dan Jam kerja pedagang kaki lima. a. Modal

Menurut Sawir (2001) modal kerja adalah keseluruhan aktiva lancar yang dimiliki oleh perusahaan atau dapat pula dimaksudkan dana yang harus tersedia untuk membiayai operasi perusahaan. Karena modal sangat menunjang sekali dalam kelancaran kegiatan perusahaan, sebagai contoh bagian produksi membutuhkan bahan baku, maka mereka harus membeli dulu bahan tersebut atau bagian pemasaran akan melakukan kegiatan promosi guna mengenalkan barang atau jasa yang mereka tawarkan pada konsumen atau bagian personalia membutuhkan pegawai baru, untuk itu dilakukan kegiatan perekrutan karyawan baru. Sedangkan Riyanto (2002) mengemukakan modal adalah barang konkrit yang ada dalam rumah tangga perusahaan yang terdapat di neraca debet maupun daya beli atau nilai tukar yang terdapat disebelah kredit. Menurut Sutrisno (2007) menyatakan bahwa modal kerja adalah dana yang diperlukan oleh perusahaan untuk memenuhi kebutuhan operasional perusahaan sehari-hari, seperti pembelian bahan baku, pembayaran upah buruh, membayar hutang dan pembayaran lainnya.

b. Lama Usaha

Didalam menjalankan suatu usaha, lama usaha memegang peranan penting dalam proses melakukan usaha perdagangan (Widya Utama, 2012). Lamanya suatu usaha dapat menimbulkan suatu pengalaman berusaha, dimana pengalaman dapat mempengaruhi pengamatan seseorang dalam bertingkah laku (Asmie, 2008). Lama pembukaan usaha dapat mempengaruhi tingkat pendapatan, lama seorang pelaku bisnis menekuni bidang usahanya akan mempengaruhi produktivitasnya sehingga dapat menambah efisiensi dan menekan biaya produksi lebih kecil daripada penjualan (Firdausa, 2013). Semakin lama menekuni bidang usaha perdagangan akan semakin meningkatkan pengetahuan tentang selera dan perilaku konsumen serta semakin banyak relasi bisnis dan pelanggan (Asmie, 2008). 
c ) Jam Kerja pedagang

Analisis Jam kerja merupakan bagian dari teori ekonomi mikro, khususnya pada teori penawaran tenaga kerja yaitu tentang kesediaan individu untuk bekerja dengan harapan memperoleh penghasilan atau tidak bekerja dengan konsekuensi mengorbankan penghasilan yang seharusnya didapatkan. Kesediaan tenaga kerja untuk bekerja dengan jam kerja panjang atau pendek adalah merupakan keputusan individu (Nicholson, 2002). Menurut Ehrenberg dan Smith (1988) keputusan untuk bekerja merupakan suatu keputusan puncak mengenai bagaimana seharusnya memanfaatkan waktu. Cara umum lainnya bagi orang-orang untuk memanfaatkan waktunya adalah dengan cara bekerja. Oleh karena itu dapat digolongkan pekerjaan itu menjadi pekerjaan yang tidak mendapatkan nafkah dengan pekerjaan mendapatkan nafkah (gaji). Jam kerja pedagang kaki lima atau jam buka kios mempengaruhi jumlah tamu yang terlayani karena pembeli tidak pasti jam kedatangannya (Artawa, 2012).

\section{METODOLOGI PENELITIAN}

\section{$\underline{\text { Jenis Data }}$}

Data yang digunakan dalam penelitian ini adalah data primer. Data primer merupakan sumber data yang langsung memberikan data kepada pengumpul data (Sugiyono, 2013). Sumber data dalam penelitian ini adalah responden yaitu pedagang kaki lima di THM Plaza yang dipilih secara acak. Data primer yang diperlukan dalam penelitian ini adalah data terkait tentang variabel modal usaha dalam satuan rupiah, lama usaha dalam satuan tahun, jam kerja pedagang dalam satuan jam perhari. Instrumen penelitian yaitu dengan menggunakan angket daftar pertanyaan yang telah dipersiapkan sebelumnya.

\section{Populasi dan Sampel}

Populasi dalam penelitian ini adalah seluruh pedagang kaki lima di THM Plaza. Sampel adalah bagian dari jumlah dan karakteristik yang dimiliki oleh populasi tersebut (Jogiyanto, 2007). Karena jumlah populasi masih dalam ukuan perkiraan dengan jumlah yang tidak pasti, maka peneliti menggunakan penentuan sampel dengan rumus wibisono (Riduwan dan Akdon, 2013). Jika digunakan

untuk mengestimasi $\mu$ kita dapat (1- $\alpha) \%$ yakin bahwa error tidak melebihi nilai e tertentu apabila ukuran sampelnya sebesar n, dimana apabila nilai $\sigma$ tidak diketahui, kita dapat menggunakan $\mathrm{s}$ dari sampel sebelumnya (untuk $\mathrm{n} \geq 30$ ) yang memberikan estimasi terhadap $\sigma$, maka standar deviasi populasinya adalah 0,25.

Apabila peneliti ingin menggunakan tingkat kesalahan 5\%, dan tingkat kepercayaan $95 \%$, dan error estimasi $\mu$ kurang dari 0,05 karena $\alpha=0,05$ maka $Z_{0,05}$ $=1,96$. Dalam pengambilan sampel, rumus sebagai berikut :

$n=\left\{\frac{\frac{Z \alpha}{2} \cdot \alpha}{e}\right\}^{2}$

$=\left\{\frac{(1,96)(0,25)}{0,05}\right\}^{2}$

$=96,04 \ldots$ dibulatkan 97

Dimana :

$\mathrm{n}=$ Jumlah sampel

$\mathrm{Z} \alpha=$ nilai tabel $\mathrm{Z}=0,05$

$\sigma=$ standar deviasi populasi

$\mathrm{e}=$ Tingkat kesalahan

Dengan demikian peneliti yakin dengan tingkat kepercayaan $95 \%$ bahwa sampel 96,04 atau 97.

\section{Alat Analisis dan Pengujian Hipotesis}

Adapun penelitian ini mengunakan model regresi linear berganda. Model regresi untuk hubungan antara variabel-variabel bebas (Modal, Jam Kerja, dan Lama Usaha) dengan variabel tidak bebas (Pendapatan). Proses analisisnya dilakukan dengan program Eviews 8, menurut Ghozali (2012) formulasinya adalah : 
$Y=\beta_{0}+\beta_{1} X_{1}+\beta_{2} X_{2}+\beta_{3} X_{3}+\varepsilon$

dimana :

$\mathrm{Y}=$ Pendapatan responden (bulan)

$\mathrm{X}_{1}=$ Modal responden (bulan)

$\mathrm{X}_{2}=$ Jam kerja responden (bulan)

$\mathrm{X}_{3}=$ Lama usaha responden (tahun)

$\beta_{0}=$ konstanta

$\beta_{1}, \beta_{2}, \beta_{3}=$ koefisien regresi

$\varepsilon=$ error terms (tingkat kesalahan)

\section{$\underline{\text { Uji Asumsi Klasik }}$}

Pengujian terhadap asumsi klasik bertujuan untuk mengetahui apakah model regresi tersebut baik atau tidak jika digunakan untuk melakukan penaksiran. Suatu model dikatakan baik apabila bersifat BLUE ( Best Linear Unbiased Estimator), yaitu bila memenuhi asumsi klasik atau terhindar dari masalah-masalah autokorelasi, heterokedastisitas, dan multikolinearitas.

\section{$\underline{\text { Uji Hipotesis }}$}

Uji statistik dilakukan untuk mengetahui besarnya masing-masing koefisien dari variabel-variabel bebas baik secara parsial atau individu maupun secara simultan atau bersama-sama terhadap variabel terikat yaitu:

a. Pengujian Secara Simultan (Uji-F)

Adapun rumus $\mathrm{F}_{\text {statistik : }}$

$$
\text { Fstatistik }=\frac{\mathrm{R} 2 / \mathrm{K}}{1-\mathrm{R} 2 /(\mathrm{n}-\mathrm{k}-1)}
$$

dimana:

$\mathrm{R}_{2}$ : Koefisien determinan berganda

$\mathrm{k}$ : Jumlah variabel bebas

$\mathrm{n}$ : Jumlah sampel

b. Pengujian Secara Parsial (Uji-t) rumus :

Nilai t-statistik diperoleh dengan

$\mathrm{t}-$ statistik $=\frac{\mathrm{r} \sqrt{\mathrm{n}-2}}{1-r^{2}}$

dimana:

$r=$ nilai korelasi parsial

$n=$ jumlah sampel

c. Uji Koefisien Determinasi (Uji R2)
Adapun Rumus dari Adjusted $\mathrm{R}_{2}$ sebagai berikut :

$\mathrm{R}^{2}=\frac{E S S}{T S S}$

dimana :

$\mathrm{R}_{2}=$ koefisien determinansi

ESS = jumlah kuadrat yang dijelaskan

TSS $=$ jumlah kuadrat total

\section{HASIL PENELITIAN}

Gambaran Umum Komplek Pertokoan THM (Tarakan Harus Membangun)

Tarakan Barat adalah salah satu dari 4 kecamatan di Kota Tarakan, Provinsi Kalimantan Utara, dengan luas 27,89 km2. Kecamatan ini memiliki jumlah penduduk hingga 84,693 jiwa dengan kepadatan sebesar 3.036 jiwa/km2 maka dapat dikatakan kecamatan Tarakan Barat merupakan kecamatan tersempit, terpadat dan terbanyak penduduknya serta menjadi pusat perekonomian di Tarakan.

Tarakan sebagai salah satu kota yang sedang membangun tidak luput dari perhatian kaum urban dan menjadi sasaran untuk sekedar mendapat penghasilan yang lebih baik dibandingkan dengan daerah asal. Sehingga mendorong tumbuh dan berkembangnya pedagang kaki lima dibeberapa tempat strategis, salah satu contohnya di THM Plaza.

Pedagang kaki lima yang berada di komplek pertokoan THM tidak diberikan izin secara tertulis dari Pemerintah Kota, mereka hanya diizinkan sebagai alternatif sementara agar tidak mengganggu ketertiban dan keindahan kota sesuai Peraturan Daerah yang ada sambil menunggu tempat yang ditentukan oleh Pemerintah Kota. Pedagang kaki lima di THM Plaza ini biasanya beroperasi dari pukul 03.00 sore sampai pukul 23.00 malam. Berdasarkan hasil penelitian lapangan, dapat diketahui bahwa sebagian besar pedagang kaki lima di THM Plaza berjualan dengan cara menggelar terpal sebagai alas untuk barang dagangan mereka. Selain itu terdapat juga pedagang 
kaki lima yang berjualan dengan memanfaatkan emperan toko baik menggunakan rombong bergerak maupun permanen. Terdapat berbagai jenis barang keperluan sehari-hari yang diperdagangkan seperti pakaian, sepatu, tas, assesoris, elektronik, mainan, alat tulis menulis, peralatan dapur, dan lain-lain. Di daerah ini prasarana maupun sarana umum cukup memadai, misalnya fasilitas yang berkaitan dengan transportasi, perdagangan, kesehatan, komunikasi, perkantoran, dan lainnya.

\section{Gambaran Umum Responden}

Hasil wawancara di lapangan diperoleh informasi bahwa umur pedagang kaki lima di THM Plaza rata-rata berada pada usia produktif yaitu kelompok umur 21 sampai dengan 50 tahun dengan total 85 pedagang atau 87.62 persen. Diketahui responden pedagang kaki lima di THM Plaza berjenis kelamin laki-laki sebanyak 51 orang atau sebesar 52,58 persen. Sedangkan pedagang kaki lima di THM Plaza yang berjenis kelamin perempuan sebanyak 46 orang atau 47,42 persen dari total responden. Pedagang kaki lima di THM Plaza yang mempunyai modal usaha diatas $\mathrm{Rp}$ 20.000.000 yaitu 3 responden sebesar 3,09 persen, sedangkan yang mempunyai modal usaha terendah yaitu kurang dari $\mathrm{Rp}$ 1.000 .000 sebesar 18,56 persen. Selain itu tingkat pendidikan dapat mempengaruhi tingkat pendapatan keluarga, karena dengan pendidikan yang lebih baik memungkinkan responden dapat mengembangkan inovasinya sesuai dengan prioritas usaha dan dari hasil penelitian di THM Plaza diketahui bahwa pedagang kaki lima yang paling dominan hanya tanat SD sebanyak 36 orang atau 37,11 persen dan yang memiliki pendidikan tertinggi hanya 1 orang yaitu lulus tingkat Strata 1. Lama usaha berpengaruh terhadap pendapatan pedagang kaki lima di THM Plaza, dimana diketahui bahwa sebanyak 50 orang atau sebesar 50,54 persen pedagang kaki lima di THM Plaza sudah berdagang antara 1 sampai 5 tahun. THM Plaza biasanya beroperasi setiap hari mulai pk. 03.00 - 23.00 Wita atau rata- rata 8 jam perhari. Dimana pedagang kaki lima di THM Plaza yang mempunyai jam kerja 5-8 jam perhari sebesar 80,41 persen dibandingkan dengan pedagang yang mempunyai jam kerja diatas 9 jam perhari sebesar 19,59 persen. Sehingga rata-rata jam kerja pedagang kaki lima mengikuti jam buka-tutup di THM Plaza yang sudah ada.

\section{$\underline{\text { Pembahasan }}$}

Dalam pembahasan ini akan dijelaskan apakah Modal, Jam Kerja, dan Lama Usaha secara parsial maupun simultan berpengaruh terhadap Pendapatan Pedagang Kaki Lima di THM Plaza.

\section{$\underline{\text { Regresi Linear Berganda }}$}

Dari hasil perhitungan regersi berganda, maka persamaan regresi berganda adalah:

$Y=\beta_{0}+\beta_{1} X_{1}+\beta_{2} X_{2}+\beta_{3} X_{3}+\varepsilon$

$Y=13,808+0,027 X_{1}+0,341 X_{2}-0,015$

$\mathrm{X}_{3}+\varepsilon$

Sehingga dari persamaan regresi linear berganda di atas, dapat dijelaskan bahwa :

- $\beta 0=13,808$

Nilai $\beta_{0}$ adalah konstanta, dengan anggapan variabel Modal $\left(\mathrm{X}_{1}\right)$, Jam Kerja $\left(\mathrm{X}_{2}\right)$, dan Lama Usaha $\left(\mathrm{X}_{3}\right)$ adalah nol atau konstan, maka pendapatan ratarata pedagang kaki lima adalah sebesar 13,808 satuan.

$-\beta 1=0,027$

Koefisien regresi Modal ( $\left.\mathrm{X}_{1}\right)$ sebesar 0,027 dan tidak signifikan artinya jika ada kenaikan satu satuan variabel Modal ( $\left.\mathrm{X}_{1}\right)$ dengan asumsi variabel independen lainnya konstan, maka hal tersebut akan meningkatkan pendapatan sebesar 0,027 satuan. Namun, hal ini tidak signifikan mempengaruhi pendapatan pedagang kaki lima karena pedagang kaki lima cenderung menggunakan pendapatannya hari ini sebagai modal usahanya besok hari contohnya pedagang makanan dan minuman. Mereka menggunakan pendapatannya hari 
ini sebagai modal operasional besok harinya dengan asumsi sebagian pendapatan dalam hal ini laba digunakan untuk memenuhi kebutuhan mereka sehari-hari. Jadi, tidak selalu jika modal bertambah maka pendapatan akan bertambah.

- $\beta 2=0,341$

nilai koefisien regresi jam kerja $\left(\mathrm{X}_{2}\right)$ sebesar 0,341 satuan. Artinya, jika jam kerja bertambah sebesar 1 satuan maka pendapatan pedagang kaki lima di THM Plaza akan bertambah sebesar 0,341 satuan dengan asumsi variabel lainnya tetap. Dari hasil tersebut dapat disimpulkan bahwa variabel jam kerja berpengaruh positif terhadap pendapatan pedagang kaki lima di THM Plaza.

Hasil uji regresi menunjukkan bahwa penambahan jam kerja dapat mempengaruhi pendapatan seorang pedagang kaki lima. Semakin tinggi jam kerja yang dicurahkan untuk berdagang maka semakin besar pula kemungkinan memperoleh pendapatan yang lebih tinggi karena semakin banyak waktu yang digunakan untuk menunggu kedatangan konsumen. Hal ini dapat dibuktikan dengan melihat nilai t-statistik sebesar 3.214 dengan probabilitas sebesar 0,001 yang nilainya lebih kecil dari 0,05 sehingga dapat dikatakan signifikan pada $\alpha=$ $5 \%$.

$-\mathrm{B}_{3}=-0,015$

Dalam hasil penelitian ini di dapat bahwa variabel lama usaha tidak memiliki pengaruh yang signifikan terhadap variabel pendapatan dengan nilai probabilitas sebesar 0,693. Dan memiliki nilai koefisien sebesar 0,015 dan bertanda negatif yang menyatakan bahwa terjadinya peningkatan 1 satuan lama usaha pedagang kaki lima yang berdagang di THM Plaza maka dapat menurunkan pendapatan sebesar 0,015 satuan. Akan tetapi karena variabel lama usaha dinyatakan tidak berpengaruh terhadap pendapatan dengan demikian meningkat atau menurunnya lama usaha tidak akan mengubah pendapatan pedagang kaki lima di THM Plaza.

\section{Pengujian Hipotesis}

a. Uji Hipotesis dengan Uji t (Parsial)

- Uji t untuk variabel Modal (X1)

Berdasarkan perhitungan regresi linear berganda dengan EViews versi 8 maka, nilai t-statistik adalah 0,869 dan nilai t-tabel adalah 1,985. Perbandingan keduanya menghasilkan : $\mathrm{t}$-statistik $=0,869<\mathrm{t}$-tabel $=$ 1,985 Karena, t-statistik < t-tabel, maka dapat disimpulkan bahwa $\mathrm{H}_{0}$ diterima dan $\mathrm{H}_{1}$ ditolak. Artinya jumlah modal tidak berpengaruh terhadap pendapatan pedagang kaki lima di THM Plaza.

- Uji t untuk variabel Jam Kerja (X2)

Berdasarkan perhitungan regresi linear berganda dengan EViews versi 8

maka, nilai t-statistik adalah 3,214 dan nilai t-tabel adalah 1,985. Perbandingan keduanya menghasilkan : $\mathrm{t}$-statistik $=3,214>\mathrm{t}$-tabel $=$ 1,985 .

Karena, t-statistik > t-tabel, maka dapat disimpulkan bahwa $\mathrm{H}_{0}$ ditolak dan $\mathrm{H}_{1}$ diterima. Artinya semakin tinggi waktu yang digunakan dalam bekerja/buka lapak maka pendapatan yang diterima pedagang sektor informal akan semakin tinggi.

- Uji t untuk variabel Lama Usaha $\left(\mathrm{X}_{3}\right)$

Berdasarkan perhitungan regresi linear berganda dengan EViews versi 8 maka, nilai t-statistik adalah $-0,395$ dan nilai t-tabel adalah 1,985. Perbandingan keduanya menghasilkan : t-statistik $=-0,395<\mathrm{t}$-tabel $=1,985$ Karena, t-statistik $<\mathrm{t}$-tabel, maka dapat disimpulkan bahwa $\mathrm{H}_{0}$ diterima dan $\mathrm{H}_{1}$ ditolak.

b. Uji Hipotesis dengan uji F (Simultan)

Perbandingan akan menghasilkan : Fstatistik $=3,676>$ F-tabel $=2,70$ Karena Fstatistik > F-tabel, maka disimpulkan bahwa $\mathrm{H}_{0}$ ditolak dan $\mathrm{H}_{1}$ diterima, hal ini menunjukkan adanya pengaruh yang kuat dan signifikan antara seluruh variabel yaitu variabel modal $\left(\mathrm{X}_{1}\right)$, jam kerja $\left(\mathrm{X}_{2}\right)$, dan lama usaha $\left(\mathrm{X}_{3}\right)$ secara simultan terhadap variabel pendapatan pedagang kaki lima (Y) di THM Plaza. 
Berdasarkan hipotesis yang dikemukakan sebelumnya modal, jam kerja, dan lama usaha secara parsial berpengaruh positif terhadap pendapatan pedagang kaki lima (Y) di THM Plaza. Dan setelah dianalisis, maka hipotesis yang dikemukakan diatas ternyata tidak terbukti karena jam kerja secara parsial berpengaruh terhadap pendapatan pedagang kaki lima di THM Plaza. Sedangkan modal dan lama usaha secara parsial tidak berpengaruh terhadap pendapatan pedagang kaki lima di THM Plaza. Berdasarkan hipotesis yang dikemukakan sebelumnya modal, jam kerja, dan lama usaha secara simultan berpengaruh signifikan terhadap pendapatan pedagang kaki lima di THM Plaza. Dan setelah dianalisis, maka hipotesis yang dikemukakan diatas ternyata terbukti atau secara simultan ada pengaruh yang signifikan antara jumlah modal, jam kerja, dan lama usaha terhadap pendapatan pedagang kaki lima di THM Plaza.

c. Uji koefisien Determinasi (Uji R2)

Dari hasil perhitungan regresi berganda pada tabel model diperoleh nilai $\mathrm{R}_{2}$ $=0,106$ artinya pengaruh variabel modal $\left(\mathrm{X}_{1}\right)$, jam kerja $\left(\mathrm{X}_{2}\right)$, dan lama usaha $\left(\mathrm{X}_{3}\right)$ dapat menerangkan variabilitas sebesar $10,6 \%$ dari variabel pendapatan pedagang kaki lima (Y) di THM Plaza, sedangkan sisanya sebesar $89,4 \%$ diterangkan oleh variabel lain yang tidak terdapat dalam model.

\section{KESIMPULAN}

Penelitian ini bertujuan untuk mengetahui pengaruh modal, jam kerja dan lama usaha secara simultan dan secara parsial terhadap pendapatan pedagang kaki lima di THM Plaza. Berdasarkan hasil analisis dan pembahasan, maka dapat disimpulkan hal-hal sebagai berikut:

1. Modal, jam kerja dan lama usaha secara simultan berpengaruh signifikan terhadap pendapatan pedagang kaki lima di THM Plaza.

2. Jam kerja berpengaruh positif terhadap pendapatan pedagang kaki lima di THM
Plaza, sedangkan variabel modal dan lama usaha tidak berpengaruh positif terhadap pendapatan pedagang kaki lima di THM Plaza.

\section{SARAN}

Berdasarkan hasil pembahasan dan kesimpulan yang telah diuraikan, dapat diajukan beberapa saran sebagai berikut:

1. Pedagang sebaiknya memliki tenaga kerja tambahan untuk membantu proses perdagangan terutama pedagang yang memiliki porsi jam kerja yang banyak. Hal ini sangat membantu pedagang dalam proses perdagangan.

2. Pedagang diharapkan menjaga kebersihan barang dagangan dan menata rapi barang dagangan sehingga konsumen yang datang merasa puas dan nyaman.

3. Untuk peneliti selanjutnya diharapkan mempertimbangkan variabelvariabel lain diluar modal, jam kerja, dan lama usaha serta mencari ruang lingkup populasi lebih luas. Dengan menggunakan variabel lain dalam melakukan penelitian diharapkan penelitian ini dapat lebih berkembang.

\section{DAFTAR PUSTAKA}

Albert Berry D.C, 2006.Firm and Group Dynamics in The Small and Medium Enterprise Sector In Indonesia. The International Bank of Reconstruction and Development / The World Bank.

Alias Radam,D.C.2013. Technical Efficiency of small and Medium Enterprise In Malaysia : A Stochastic Frontier Production Model. Journal of Economic and Management.

Anonim, 2003. Undang-Undang Nomor 20 Tahun 2008 tentang Usaha 
Mikro, Kecil dan Menengah (UMKM).

Anonim,2012. Kementerian Koperasi dan Usaha Kecil Menengah.

Ariyani,2006. Perilaku Konsumen, Bandung. Artawa,2012. Pasar Seni Sukawati Orientasi Sekolah Tinggi Pariwisata Nusa Dua, Dinas Pendapatan Kabupaten Gianyar.

Asghar Afshar D.C, 2012. The Relationship between Goverment Policy and The Growth of Entrepreneurship in the Micro, Small and Medium Enterprises of India.

Asmie, Poniwati. 2008."Analisis FaktorFaktor Yang Mempengaruhi Tingkat Pendapatan Pedagang Pasar Tradisional Di Kota Yogyakarta”. (tesis). Yogyakarta : Universitas Gadjah Mada.

Azwar, Saifuddin. 2007. Metode Penelitian, Pustaka Pelajar, Yogyakarta.

Bhowmik dan Tadjuddin Noer Effendi. 2005. Peranan Sektor Informal, Yayasan Obor Indonesia, Jakarta.

Buchari, Alma. 2006. Pemasaran dan Pemasaran Jasa, Alfabeta, Bandung.

Budi, 2006. Kajian Lokasi Pedagang Kaki Lima Berdasarkan Preferensi PKL Serta Persepsi Masyarakat Sekitar di Kota Pemalang.

Daron, 2004. Analisis Faktor-Faktor Yang Mempengaruhi Tingkat Petani Garam di Kabupaten Cirebon.

Fatmawati, 2014. Analisis Faktor-Faktor Yang Mempengaruhi Pendapatan Pedagang Kaki Lima Di Pasar Raya Padang.

Ehrenberg dan Smith, 1998. Modern Labor Ekonomis, Theory and Publics Policy Iuns, Fresnient and Company.

Firdausa dan Arianti, 2013. Pengaruh Modal Awal, Lama Usaha, dan Jam
Kerja Terhadap Pendapatan Pedagang Kios Di Pasar Bintaro Demak.

Gujarati, Damodar. 2009. Ekonometrika Dasar. Buku I edisi 5, Salemba Empat, Jakarta.

Ghozali, Imam. 2005. Statistik Untuk Penelitian, Jakarta.

Ghozali, Imam. 2012. Aplikasi Analisis Multivariat dengan Program Eviews. Cetakan IV, Badan Penerbit Universitas Diponogoro, Semarang.

Hanni, Sofia. Memperkuat Struktur Permodalan UMKM. Laporan diunduh dari http://www.pelita.or.id/cetaka rtikel.php?id=33124

Hentiani Tri L, 2012. Analisis Faktor-Faktor Yang Mempengaruhi Pendapatan Pedagang Informal di Pasar Sentral Medan, Tesis Jurusan Ekonomi Pembangunan Universitas Sumatera Utara.

Hill, Hal."Small and Medium Enterprises In Indonesia : Old Policy Challenges for a New Administration". Asian Survey XLI no.2 (April 2001).

Husaini, Usman. 2003. Metodologi Penelitian Sosial, Bumi Aksara, Jakarta.

Jogiyanto H.M, 2007. Metodologi Penelitian Bisnis : "Salah kaprah dan pengalaman-pengalaman", Edisi ke enam, BPFE Yogyakarta.

Lincolin, Arsyad. 1993. Ekonomi Pembangunan, STIE YKPN, Yogyakarta.

Manning, Chris dan Roesad. 2006. Urbanisasi, Pengangguran, dan Sektor Informal Di Kota, Gramedia, Jakarta.

Munandar, M. 2006. Pokok-Pokok Intermediate Accounting, Universitas Gadjah Mada. 
Nicholson, W. 2002. Mikroekonomi Intermediate, Edisi Kedelapan, Erlangga, Jakarta.

Riduwan dan Akdon, 2013. Metodologi Penelitian, PT Raja Grafindo Persada, Jakarta.

Riyanto, Bambang. 2002. Dasar-Dasar Pembelanjaan Perusahaan, Edisi Tiga Cetakan Ketujuh Belas, Penerbit Yayasan Gadjah Mada, Yogyakarta.

Samuelson, Paul A. William D. Nordhaus, 2002. Makro Ekonomi, Edisi 12 jilid 2, Penerbit Erlangga, Jakarta.

Sawir, Agnes. 2001. Analisis Kinerja Keuangan dan Perencanaan KeuanganPerusahaan, Gramedia Pustaka Utama, Jakarta.

Setio P, Zhafril. 2015. Faktor-Faktor Yang Mempengaruhi Pendapatan Pedagang Kaki Lima Kota Malang (Study Kasus Pedagang Kaki Lima di Wisata Belanja Tugu Kota Malang).

Sudha, Venkatesh. 2006. SMes In India : Importance an Contribution. Asian Journal of Management Research, Research Article ISSN 222-3795.

Sugiyono, 2013. Metode Penelitian Bisnis, Cetakan Enam Belas. CV Alfabeta, Bandung.

Sukirno, Sadono. 1994. Pengantar Teori Ekonomi Makro, Penerbit Raja Grafindo, Jakarta.

Sukirno, Sadono. 2000. Pengantar Teori Makro Ekonomi, PT Rai Grafindo Persada, Jakarta.

Sukirno, Sadono. 2005. Mikro Ekonomi Teori Pengantar, Edisi Ketiga, Raja Grafindo Persada, Jakarta.

Suparmoko, 2000. Keuangan Negara Dalam Teori Dan Praktek, BPFE Yogyakarta.

Sutrisno, 2007. Manajemen Keuangan Ekonesia, Yogyakarta.
Struyk, Raymond J. 2011. Which Indonesian Small and Medium Firms Use Formal Financial Services?. Journal of Economic and Finance, Vol 3 No.4.

Tambunan, Tulus. 2002. Usaha Kecil dan Menengah di Indonesia : Beberapa Isu Penting, Penerbit Salemba Empat, Jakarta.

Tambunan, Tulus. 2009. UMKM di Indonesia, Ghalia Indonesia, Jakarta.

Todaro, 2000. Pembangunan Ekonomi Di Dunia Ketiga, Edisi Ketujuh, Erlangga, Jakarta.

Tuanakota, M Theodurus, 2000. Teori Akuntansi, Lembaga Penerbit FE-UI, Jakarta.

Wibowo, 2005. Manajemen Kinerja, Edisi Ketiga, Rajawali Pers.

Widarjono, Agus. 2007. Ekonometrika Teori dan Aplikasi untuk Ekonomi Bisnis, Ekonesia, Yogyakarta.

Widya Utama, I Gusti Bagus Adi, 2012. "Faktor-Faktor yang Mempengaruhi Pendapatan Pengusaha Perak Di Desa Celuk Kecamatan Sukawati Kabupaten Gianyar" (tesis), Universitas Udayana, Denpasar.

Yusuf Yusbar dkk, 2010. Implikasi Program Nasional Pemberdayaan Masyarakat (PNPM) Mandiri Pedesaan Terhadap Pendapatan Pedagang Kecil Di Kecamatan Langgam Kabupaten Pelalawan Propinsi Riau Tahun 20072010. Journal of Economics. Fakultas Ekonomi Universitas Riau 